\title{
Information Systems Use Of Funds To The Government Of The Transparent
}

\author{
Pratomo Setiaji ${ }^{1}$, Wiwit Agus Triyanto ${ }^{2}$, Arif Setiawan ${ }^{3}$, Diana Lalily Fithri ${ }^{4}$ \\ \{pratomo.setiaji@umk.ac.id'1,wiwit.agus@umk.ac.id ${ }^{2}$, arif.setiawan@umk.ac.id ${ }^{3}$ \} \\ Information System, Faculty of Engineering, Universitas Muria Kudus, Gondangmanis, PO Box 53, \\ Bae, Kudus 59352 1234
}

\begin{abstract}
Kudus received a substantial village fund allocation, the allocation of funds transferred to the village government in Kudus Regency, Central Java, to support village development in 2017 reached Rp 219.89 billion. Problems that can arise in their use include: Administration of financial statements: Reduction of Village Fund allocations, Can not be held accountable for the use, misappropriation of village assets, Rental of Village Treasury Land (TKD) which is not his right. These problems can be overcome by presenting good and transparent information, for this purpose an information system for using village funds (SIMDANDES) is needed for village fund management received by Gondangmanis village, Kab. Kudus District with Information Retrieval System, System (SIMDANDES) Algorithm very useful for monitoring village fund use and uptake carried out in each village in real time, as well as information for village heads and policy makers in Kudus District to establish a policy.
\end{abstract}

Keywords: government, information systems, the village fund, transparent.

\section{Introduction}

The Ministry of Rural Development of Disadvantaged Regions (PDT) and Transmigration village will distribute funds amounting to Rp 1.4 billion for each village. This funding is done gradually until the next five years, to 2015 which was launched there were approximately $\mathrm{Rp}$ 9.2 trillion.

Kudus District is one district that receives funds the village, with the conditions of geographically located at the crossroads of major transportation Jakarta-Semarang-Surabaya and Jepara-Grobogan, Kudus is a very strategic area and rapidly developed and has a leading role as a center of economic activity airport area surrounding districts. Kudus is the smallest district in Central Java with a total area of 2,516 hectares and is divided into nine districts, villages in Kudus regency which totaled 123 this year to get the village fund allocation of Rp 1.4 billion, according to the Head of the Village Administration Kudus District Adi Sadhono said, the village fund allocation will not be shared equally. Allocation of funds for each village adapted to a number of criteria such as population, level of welfare, as well as a number of other criteria.

The research presents the e-government platform that supports easy public access to government information, e-transactions between residents and community organizations through the acceptance of e-document [1].

ICCSET 2018, October 25-26, Kudus, Indonesia

Copyright (C) 2018 EAI

DOI 10.4108/eai.24-10-2018.2280620 
E-commerce can be used by various parties to improve business processes such as enterprise, B2B model to integrate the companies, partners, suppliers and distributors. The method used in this research is the method of system development FAST (Framework for Implementation of Mechanical Systems) with a prototyping approach[2].

The three main goals of the effort to implement the IS / IT in an organization. First, improve work efficiency by automation of various processes that manage information. Second, increase management effectiveness by satisfying the information needs for decisionmaking. Third, improve the competitiveness or increase the competitive advantage of organizations by changing the style and way of doing business[3]. In this journal will be published the results of research that has been done on the analysis and design of information systems in the district of Kudus village funds with waterfall method. in an effort to help local governments in the management of funds of funds so that the information can be informed in good village.

\section{Methodology}

In line with the objectives to be achieved in this study, the analysis and design of information systems fund village in the district of Kudus with waterfall method, this research is done by using studies (research) to the development models that have been implemented and then based on the results of the study was to formulate the analysis and design of information system design analysis of village funds, then from the system design models developed into a model information system applications. Stages of the research process that is done is shown in Figure 1.

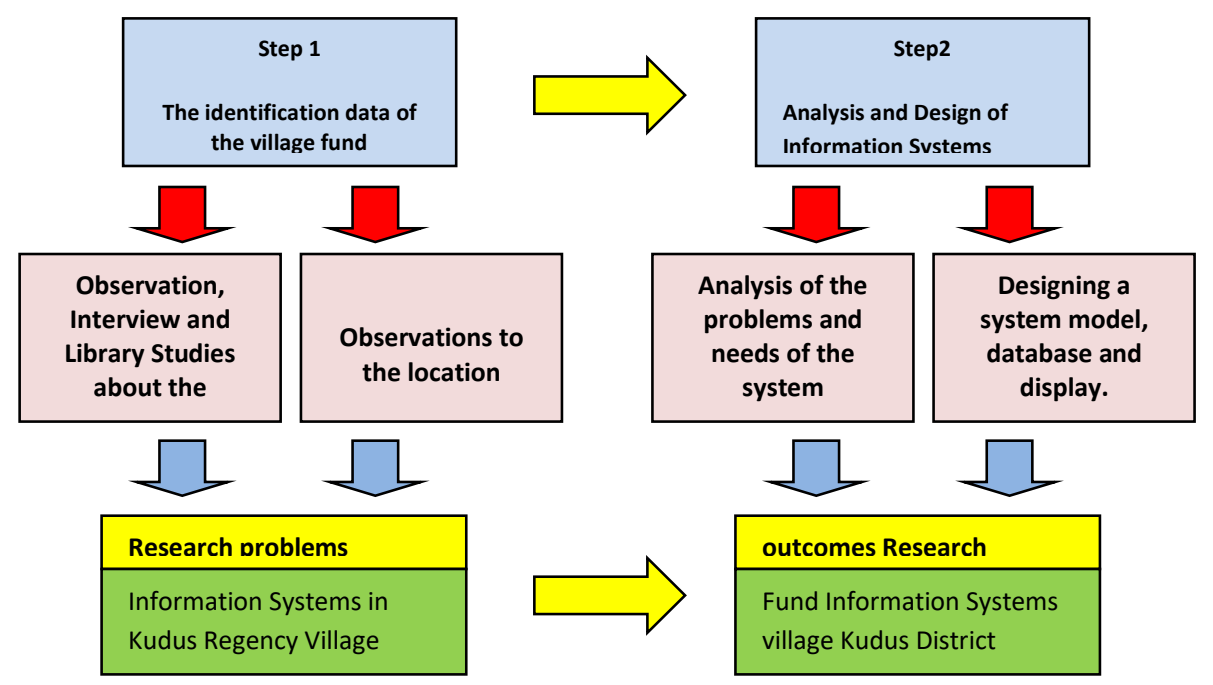

Fig 1. Stages of the research process. 
The research location is in Kudus, with the data source Kudus village in the county, and Engineering Laboratory research in software, Information Systems Studies Program Faculty of Engineering, University of Muria Kudus.

Variables used in the design process of this analysis is the amount of revenue the budget format and budget management will be allocated as expenditure and rural development in Kudus district.

The design models used in building information systems Dana village in Kudus regency are using design OOD (Object Oriented Design) and the tool used is the Unified Modeling Language (UML). UML generally offers a graphical model of a system by using different groups based on its functionality. All UML diagram or models prepared by the development expert are based on the various perspectives of the data and information system[4]. The different types of UML diagrams and their objects are briefly discussed here: (i) Use Case Diagrams: By using various type of graph, the structure illustrate the connections among the internal systems and also different external systems along with end users[5].

Object-oriented analysis and design (OOAD) is a globally accepted technical process for manipulative an application specific, business or system model, and simple graphical diagram for analyzing and product quality improvement by applying the object-oriented prototype method[6].

Object Oriented Analysis (OOA) is basically collected works of concurring or cascading system modelling, incorporate various requirements and pre and post analysis methodology for software systems. These methodologies are primarily influenced by different objectoriented programming, data modelling and systematic interconnections[7]. Fundamental idea behind OOA is a streamline software design and development by considering all model as a discreet objects, classes, methods and by linking these one can designs and implement all kind of business requirements [7]. It mainly focused on the system development and analysis. This study also focus on how it make compatible with newly develop or other existing business computing application in better way. In the late $80^{\circ} \mathrm{s}$ and $90^{\circ} \mathrm{s}$ there were many different object - oriented.

Methods and modelling techniques used what limited sharing of models across projects (reduced reusability) and hampered communication between team members and users. The main objective of any model is to build a distinct, globally accepted standard procedure for object-oriented systems software [8]. Unified Modelling Language (UML) is one of the standard widely accepted languages, generally is used for modelling any system considering as objects for better analysis [9]. Such techniques mainly focus on the modelling of the exact procedure or near to the exact procedure within its application domain which may model by using different objects class. These methodologies may used different generalization, classification and different aggregation as a structure object assemblies for the target actions like services or activities which are related with the objects. It can be implemented by MATLAB also [10]. The major difficulty of preventing object oriented code and reuse code by different attackers is a major challenge [11].

OOD is a method that brings us to the object-oriented decomposition. By applying objectoriented design, we can create a formidable software by minimizing the writing of expression as well as reduce the risk inherent in the development of complex software systems [12]. Design models are included in the UML use case diagrams, class diagrams, sequence diagrams, activity diagrams, state diagrams, collaboration diagrams.

Techniques of collecting and analyzing data in this study is the observation, literature, and interviews. The observations were made to the location of the village in Kudus, interviews were conducted with data sources such as the party of the village in the district of Kudus and 
research samples and literature by searching the literature and journals on Information Systems.

Data analysis done in three stages, namely: (1) identify and analyze problems running system (problem analysis), in this case to analyze the constraints in the admissions process and the management of village funds that have been used over the years, (2) identify and analyze the criteria and the required system performance (requirements analysis), in this case carried out an analysis of the criteria the village needed money system, (3) provide an alternative to the proposed system (generating alternative systems). In this section performed along with system selection input, process and output of the village fund information system tailored to the needs.

\section{Results and Discussion}

In accordance with the methodology of the research that has been set, the following are the results that have been achieved.

\subsection{Analysis System}

The concept of village funds information system has been implemented using a single parameter, namely the amount of revenue and management of village fund. The process of the use of information systems is not implemented on a scheduled basis, only if there was a reception and fund management that has been given by the government, then the use of the information system will be put in a database and only written in the book.

In practice the use of the information system still needs a lot of improvement and further development, improvement is still needed is to change based manual be based computerized system that not only users of the system who can see and use this information system but the policy makers and the general public can view and monitor whether the management and receipt of funds is in conformity with the needs of the community

Improvement and further development will certainly be very bermaanfaat if further research so that the data will be more accurate and be able to provide information to agencies and to the government so that the information can be displayed quickly and accurately so it does not take long in processing data into an information

\subsection{Needs analysis}

After seeing the analysis of the problems above, the criteria and a new system is needed is a system that can help the village in the district of Kudus in the process of fund management of the village, with the capability of the system as follows: (1) The application system can process incorporate budgetary funds received from government right, (2) the application system can also generate reports relevant funds, (3) report on the management of the funds can be displayed quickly and accurately, so they can know the reception and management for the betterment of the village. To analyze the criteria and systems required, the steps are as follows. 


\subsubsection{Identification Data}

Data reception by the village received assistance from industrialized governments which are used for the development of rural attributes data identified include (1) the amount of funds the village received, (2) the plan penegembangan village using village funds and (3) the implementation of the management of village fund created for developing a village.

\subsubsection{Analysis of Information}

Information needed is the information system users the village fund. Users of the system are the villages of the district staff and stakeholders at the Holy Holy District.

\subsection{System design}

The results of the analysis that has been done then poured into a model of the system in the form of the diagram, the details of the structure of the data storage and display layout application that will be generated.

\subsubsection{Use Case Diagram}

Use case is the specification of a set of actions executed by the system. Use case diagram for the village fund information system are shown in Figure 2.

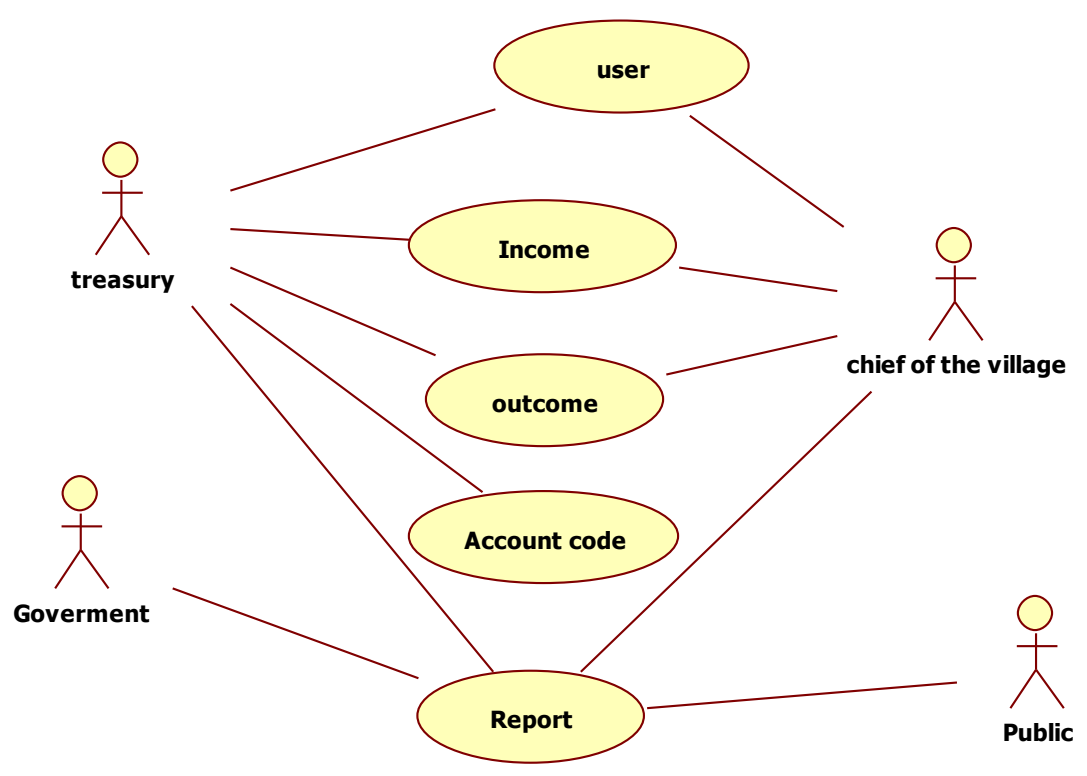

Fig. 2. Use Case. 


\subsubsection{Structure of Data Storage}

Database application that is used to develop applications is the MySQL database server that is opensource. There is a database designed in a village fund applications that dbdanadesa. Dbdanadesa database has three tables namely tb_Rekening, tb_anggaran and tb_user. Relations between the tables and the structure shown in Figure 3.
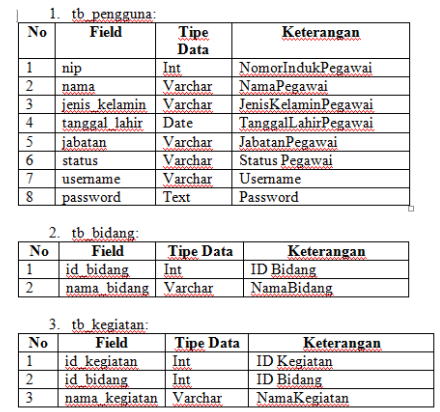
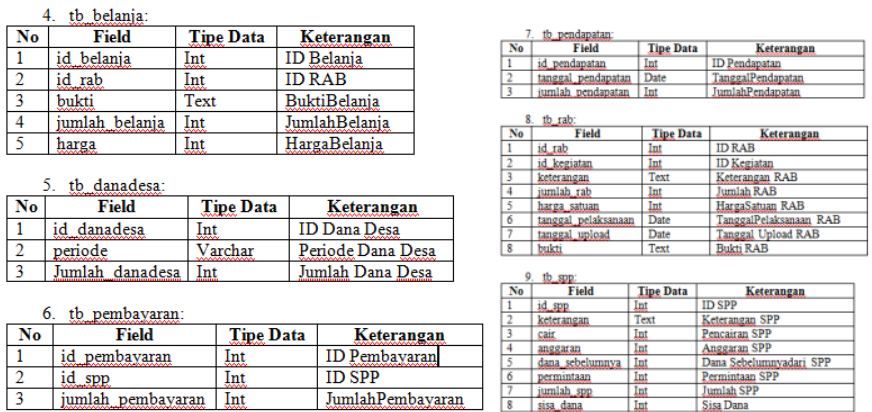

Fig. 3. The tables structure.

\subsection{Diagram Layout}

This application is built using web-based to implement the concept of village funds. Display design will be adapted to the application to be used. In figure 4 is shown a dashboard view and figure 5 of the layout view login.

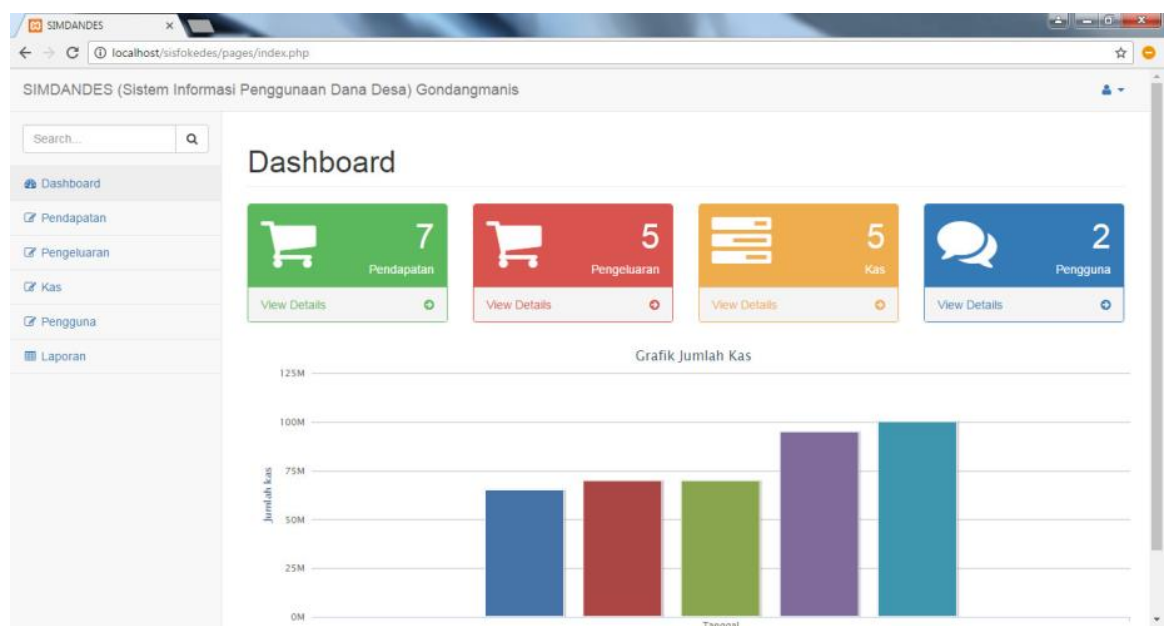

Fig. 4. Dashboard. 


\section{Login to SIMDANDES Q}

Masukkan username dan password Anda:

\section{Username}

Password

\section{Remember Me}

\section{Login}

Fig. 5. Login.

\section{Conclusion}

From the research that has been done can be concluded that:

1) Analysis of information system design through the village funds generated usecase diagram provides the facility to use the application in the reception and the village fund.

2) Amalisa village fund information system design provides an alternative for users to get any work done using a computerized system.

3) Analysis of the village fund information system design uses three tables namely tbanggaran, tbrekening and tb_user.

\section{References}

[1] A. S. Drigas and Lefteris Koukianakis, "E-Government Applications for the Information Society," IJCSI Int. J. Comput. Sci. Issues, vol. 10, no. 1, 2013.

[2] M. F, Ruskan E L, and P. A, "Penerapan Model B2B Pada Sistem Informasi Berbasis Web (Studi Kasus Pt Semen Baturaja Persero)," JSI, vol. 2, 2010.

[3] Ward, John, and J. Peppard, Strategic Planning for Information System 3nd. 2002.

[4] S Chaki, S. K. Rajamani, and J Rehof, "Types as Models: Model Checking Message-Passing Programs," POPL, ACM SIGPLAN Not., vol. 37, pp. 45-47, 2002.

[5] M. Dezani-Ciancaglini, D. Mostrous, N Yoshida, and S. Drossopolou, "Session Types for ObjectOriented Languages,” ECOOP, Springer LNCS, vol. 4067, pp. 328-352, 2006. 
[6] G Castagna, "Object-Oriented Programming A Unified Foundation," Springer Sci. Bus. Media, 2012.

[7] A Igarashi and N. Kobayashi, "Resource Usage Analysis," ACM Trans.on Program. Lang. Syst., vol. 27 , pp. 264-313, 2005.

[8] S J Gay, V T Vasconcelos, A. Ravara, N. Gesbert, and A. Z. Caldeira, "Modular Session Types for Distributed Object-Oriented Programming," ACM Sigplan Not., vol. 45, pp. 299-312, 2010.

[9] N Thota and R. Whitfield, "Holistic Approach to Learning and Teaching Introductory ObjectOriented Programming,” Comput. Sci. Educ., vol. 20, pp. 103-127, 2010.

[10] Jim Conallen, Building Web Applications with UML. Pearson, 2002.

[11] Richard D Neidinger, "Introduction to Automatic Differentiation and MATLAB Object-Oriented Programming," SIAM Rev., vol. 52, pp. 545-563, 2010.

[12] F Schuster et al, Counterfeit Object-Oriented Programming: On the Difficulty of Preventing Code Reuse Attacks in C++ Applications. 2015. 